\title{
Application of Modelling Technique in Enhancing Low Academic Self-Concept of Secondary School Students
}

\author{
Nwokolo Chinyelu; Mokwelu, Obianuju Blessing \\ Department of Guidance and Counselling, Faculty of Education, Nnamdi Azikiwe University, Awka, Nigeria
}

\begin{abstract}
This study investigated the effects of modelling technique in enhancing low academic self-concept of senior secondary school students in Onitsha education zone. One research question guided the study, while two null hypotheses were tested at 0.05 level of significance. The design for the study is quasi-experimental, non-randomised pre-test and post-test, control group research. The target population of this study was 988 senior secondary school students having low academic selfconcept in Onitsha education zone. A sample size of 108 students was selected using purposive sampling technique. A validated instrument for data collection was Academic Self-concept Survey (ASS). The internal consistency reliability coefficient for the instrument is $\mathbf{0 . 8 4}$. Data was collected through direct delivery of the instrument to the respondents. Mean scores were used to answer the research question, while the null hypotheses were tested using Analysis of Co-variance (ANCOVA). The instrument norm 72.50 guided the decision. The finding of the study revealed that Modelling technique enhanced the academic self-concept of the secondary school students but the effect was not significant when compared with those who received conventional counselling; the findings further revealed that the difference in the effect of Modelling technique on male and female secondary school students' Academic self-concepts is not significant. Based on the findings and implications of the study, it was recommended that the practicing counsellors and therapist should make use of the modelling in combination with other effective techniques in administering counselling and therapy of secondary school students to modify and enhance their academic self-concept.
\end{abstract}

Keywords: Modelling, technique, enhancing, academic, selfconcept, students

\section{INTRODUCTION}

$\mathrm{S}^{\mathrm{c}}$ elf-concept is an important building block for understanding human behaviour and learning. In recent times, the enhancement of children's self-concepts has become a desirable educational goal in the world. Educational and social policy statements emphasise the importance of developing and maintaining positive self-concepts as important educational objectives. The achievement of positive academic self-concepts, as Marsh and Craven (1997) have shown, has had an impact on academic behaviour, academic choices, educational aspirations and subsequent academic achievement.

Self-concept would even be more essential for secondary school students today as they grapple with different challenges, stressors and opportunities that may arise from a low perception of their academic abilities. Feeling low selfconcept can have devastating consequences, as it could inhibit the individual from developing desired relationships, hinder feelings of happiness, create anxiety, and limit personal aspirations and achievements. A study by Hattie (2012), which examined more than 800 meta-analyses from 50,000 research articles, identified self-concept as one of the 150 influences on student academic achievement.

Self-concept could be seen as a perception that individuals have a value of their own. This includes a combination of their feelings, a generalised perception of their social acceptance, and their personal feelings about themselves (Frank, 2011). The child's self-concept could be either high or low. Such a child with a high self-concept would probably appreciate himself and recognise self-worth, self-control and competence, with a corresponding positive attitude and a high self-assessment. On the other hand, a child with a low selfconcept would most likely have low self-assessment, selfcriticism, and a feeling of hopelessness. Such situation where students have either high or low self-concept does not just happen; it results from the developmental consequence of the child's learning both within and outside school.

In the view of Dramanu and Balarabe (2013), self-concept develops as a result of one environmental experience and one assessment of that experience. The educational years of a child's life are an important time for a child to develop a positive self-concept. Thus, for those in secondary school, their self-awareness of their academic abilities tends to be a significant part of their school adaptation and success. According to Liu and Wang (2008), the academic selfconcept, which is a sub-domain of general self-concept, shows students' perceptions of their academic abilities formed in conjunction with peers, teachers and parents.

Academic self-concept could generally be seen as the way a learner sees his or her academic ability. Hardy (2013) defines academic self-concept as students' perception of their competence and commitment to, involvement and interest in school work. These perceptions could be formed by students' experience with the environment and can be influenced, in particular, by environmental reinforcement and significant others. The actions of the individual influence their self- 
perceptions and self-perceptions, and in turn influence their actions. From the above, the academic self-concept in the context of this study is seen as how secondary school students view their academic abilities, involvement and interest in school work.

Academic self-concept is important for secondary school students' personal adjustment and for the influence it has on other desired educational outcomes such as academic achievement, educational aspirations, school completion and possibly, subsequent university attendance. The link with these outcomes as observed by Liem, McInerney and Yeung (2015) is based on the idea that individuals are likely to accomplish more if they feel more competent, have high selfconfidence and have more positive perceptions of themselves. Thus, students who are desirous of good academic achievement are expected to have high academic self-concept.

Finding by La Shawn (2011) provided an important direction for determining academic self-concept enhancement. The enhancement techniques to improve academic self-concept have been designed based on one of two approaches. The first was a self-enhancement orientation that targeted the selfconcept directly through the use of praise and performance feedback. The second as Clark (2016) noted was a skill development orientation in which constructs related to selfconcept, such as academic achievement was targeted, affecting the academic self-concept indirectly.

Modelling for instance is an important behaviour modification technique that could be used to improve the self-concept of students in schools. It is defined as a method used in psychotherapy whereby the client learns by imitation, without any specific verbal direction by the therapist (Westen, Burton, Kowalski, 2006). As McLeod (2016) noted, the use of modelling in psychotherapy was influenced by the research of social learning theorist Albert Bandura, who studied observational learning in children. Bandura through the study pioneered the concept of vicarious conditioning, by which one learns not only from the observed behaviour of others but also from whether that behaviour is rewarded or punished. Bandura established that certain conditions determine whether or not people learn from observed behaviour. From Bandura point of view, it could be asserted that students learn from observed behaviour, they must pay attention and be able to retain what they have observed, and they must be capable of and motivated to reproduce the behaviour.

As a therapeutic technique for changing one's behaviour, modelling has been especially effective in the treatment of phobias. Beyond phobias, modelling also has wide application in varying therapies (Nnodum, 2010). For example, modelling in Nnodumhas been used effectively in anger management and in reduction of isolate behaviour in children. Therapists could also use the modelling technique to illustrate healthy behaviours that clients can learn by example and practice in session. The therapist for instance could model to the secondary school students a variety of responses to difficult situations. A behaviour modelled would likely increase the student's belief about what is possible, thereby enhancing the student's ability to accomplish the task set forth and helping them to adjust in a given social situation in schools.

Schools offer one of the largest arenas for modelling where teachers and counsellors can first demonstrate the behaviour they seek so that the students can emulate the behaviour. Behaviours that students usually suppress or inhibit may be performed more readily under the influence of such models. This researcher thus is of the opinion that modelling could affect the research participant's perceptual responses to stimuli. As a consequence, modelling could determine not only what the research participants do but also their selfconcept. Treatmentdirected towards improving academic selfconcept could be designed based on the modelling approaches. Hence, this study was conceived to investigate the effects of modelling technique on the academic selfconcept of secondary school students.

\section{Statement of the Problem}

Modelling (observational learning) has been shown in literature to be effective as a method of learning such behaviours as self-disclosure, helping others, empathic behaviours, moral judgment, and many other interpersonal skills. It has also proved effective in eliminating or reducing such undesirable behaviours as uncontrolled aggression, smoking, weight problems, and single phobias. So, it is the belief of this researcher that since modelling is effective in handling the aforementioned problems, it would likely have effect in bolstering the academic self-concept of secondary school students.

Even though researchers have investigated modelling in modifying undesirable behaviours, none of the studies investigated the effect of modelling to determine its effect on low academic self-concept of secondary school students in Onitsha Education zone. This is a gap in literature that needs to be filled. This study therefore was conceived to fill the gap by investigating the effect of the technique of modelling and assertiveness in enhancing low academic self-concept of secondary school students in Onitsha Education Zone, Anambra State.

\section{Purpose of the Study}

The main purpose of this study is to determine the effect of modelling technique in enhancing low academic self-concept of senior secondary school students in Onitsha education zone. Specifically, the study seeks to determine:

1. The effect of modelling technique in enhancing low academic self-concept of secondary school students when compared with those who received conventional counselling using their pre-test and post-test scores.

2. Differences in the effects of modelling technique in enhancing academic low academic self-concept of male and female secondary school students when compared using their gained mean scores. 


\section{Significance of the Study}

The result of this study will be beneficial to all the stakeholders in the education sector including the students, guidance counsellors, teachers, parents and guardians. The findings of this study will be beneficial to students, especially those who have low academic self-concept. The students will likely benefit from the counselling and therapeutic application of the techniques.

Parents and guardians of secondary school students will also benefit from the findings of this study. This will be achieved by way of sensitizing them on how they could serve as a model in order to boost the academic self-concept of their children, especially the students.

\section{Research Questions}

The following research questions guided the study:

1. What is the effect of modelling technique in enhancing low academic self-concept of secondary school students when compared with those who received conventional counselling using their pre-test and post-test scores?

\section{Hypotheses}

The following null hypotheses were formulated to guide the study and were tested at the 0.05 level of significance:

1. The effect of modelling technique in enhancing low academic self-concept of secondary school students when compared with those who received conventional counselling using their pre-test and post-test scores is not significant.

2. The difference in the effects of modelling technique in enhancing academic self-concept of male and female secondary school students when compared using their gained mean scores is not significant.

\section{METHOD}

\section{Research Design}

This study is a non-randomized pre-test, post-test, control group quasi-experimental research. The study involved two treatment conditions (Experimental and Control group) for the students having low academic self-concept.

\section{Research Setting:}

The study was conducted in Onitsha Education Zone of Anambra State, located in the South East Geo-Political Zone of Nigeria. Many students in this area are showing signs of negative self-concepts which tend to inhibit students' learning capacity. Negative experiences during these influential years can potentially set a student back for the rest of his or her life.

\section{Participants:}

The sample of the study comprised 108 students selected from a population of 988 students. The population comprised all the students with low academic self-concept. The selection was based on the degree of their low self-concept indicated by their pre-test scores obtained through administration of the questionnaire.

\section{Instrument for Data Collection:}

Academic Self-concept Survey (ASS) was used for data collection. This is a psychometric survey instrument which was developed and validated to measure students' selfconcept as it relates to peer interaction, academic, thought, schools and home.The internal consistency reliability of the instrument "Academic Self-Concept Survey (ASS)" using Cronbach's alphas indicated a high reliability coefficient of 0.84 .

\section{Experimental Procedure}

The researcher obtained the approval of the schools' management for carrying on with the research through a consent letter that was given to the management. The experimental training sessions then took place at the two schools chosen for the study. The researcher, with the assistance of the guidance counsellors in the schools conducted a training programme which held for eight weeks for both the treatment and control group. The treatment sessions were carried out in the school's counselling centres. The day and time for each group's training was established and maintained throughout the treatment.

Each training session lasted for 45 minutes using the counselling scheduled periods as specified by the schools. The participants in the experimental groups were trained on Sociocognitive Skills while those in the control group were received the usual conventional group counselling. Each of the groups received training for the eight weeks. After the eight weeks of treatments, the Academic Self-Concept Survey (ASS) was readministered on all the participants in both the experimental and control groups. The scores obtained were stared as the post-test. The post-test scores along with the earlier elicited pre-test scores were then collated and statistically analysed.

\section{Control of Extraneous Variables:}

The researcher controlled the possible effect of extraneous variables such as participant's mood, location, discrimination, method, and time of the day which if not well controlled may contaminate the study and possibly interfere with the findings.

\section{METHOD OF DATA ANALYSIS}

The completed instruments were scored following the scoring instructions provided in the Buss-Perry Aggression Questionnaire (BPAQ) manual. The research question wasanswered using statistical Mean while the null hypotheses were tested using the Analysis of Co-variance (ANCOVA). When the post-test mean score of a group is below the norm of 70.27 , the treatment technique for that group is considered "not effective", while scores below the norm is considered "effective". For the null hypotheses, when the pvalue is less than 0.05 level of significance, the null hypotheses is rejected, 
but accepted when the pvalue is less than the level of significance.

\section{RESULTS}

The data analysed are presented as follows:

\section{Research Question}

What is the effect of modelling technique in enhancing low academic self-concept of secondary school students when compared with those who received conventional counselling using their pre-test and post-test academic self-concept scores?

Table 1: Pre-test and Post-test academic self-concept enhancement mean scores of students treated with Modelling technique and those treated with conventional counselling (Norm=72.50)

\begin{tabular}{|c|c|c|c|c|c|}
\hline $\begin{array}{c}\text { Source of } \\
\text { variation }\end{array}$ & $\mathrm{N}$ & $\begin{array}{c}\text { Pre-test } \\
\text { Mean }\end{array}$ & $\begin{array}{c}\text { Post- } \\
\text { test } \\
\text { Mean }\end{array}$ & $\begin{array}{c}\text { Gained } \\
\text { Mean }\end{array}$ & Remark \\
\hline $\begin{array}{c}\text { Modelling } \\
\text { Technique }\end{array}$ & 32 & 61.22 & 71.75 & 10.53 & $\begin{array}{c}\text { Not } \\
\text { effective }\end{array}$ \\
\hline Control & 30 & 63.23 & 70.47 & 7.24 & \\
\hline
\end{tabular}

Table 1 shows that the students treated with Modelling technique had pre-test mean score of 61.22 and post-test mean score of 71.75 with gained mean 10.53 in their Academic selfconcept, while those in the control group who received conventional counselling had pre-test mean score of 63.23 and post-test mean score of 70.47 with gained mean of 7.24 . Therefore, with post-test mean score of 71.75 which is slightly below the norm of 70.27, Modelling technique is not effective in enhancing Academic self-concept of secondary school students in Onitsha Education zone.

\subsection{Testing the Null Hypotheses}

\section{Null Hypothesis 1}

The effect of Modelling technique on secondary school students' Academic self-concepts when compared with those who received conventional counselling using their mean scores is not significant.

Table 2: ANCOVA on the Academic self-concept post-test mean scores of students treated with Modelling technique and those who received conventional counselling

\begin{tabular}{|c|c|c|c|c|c|c|}
\hline $\begin{array}{l}\text { Source of } \\
\text { Variation }\end{array}$ & $\begin{array}{c}\text { Sum of } \\
\text { Square } \\
\text { s }\end{array}$ & df & $\begin{array}{l}\text { Mean } \\
\text { Square }\end{array}$ & $\begin{array}{l}\text { Cal. } \\
\text { F }\end{array}$ & $\begin{array}{c}\text { Pval } \\
\text { ue }\end{array}$ & $\begin{array}{l}\text { De } \\
\text { cis } \\
\text { ion } \\
\end{array}$ \\
\hline Corrected Model & 32.772 & 2 & 16.386 & & & \\
\hline Intercept & $\begin{array}{c}1964.6 \\
03\end{array}$ & 1 & 1964.603 & & & \\
\hline PRETEST & 7.271 & 1 & 7.271 & & & \\
\hline $\begin{array}{c}\text { TREATMENT_G } \\
\text { ROUP }\end{array}$ & 19.038 & 1 & 19.038 & $\begin{array}{l}1.8 \\
11\end{array}$ & .184 & NS \\
\hline Error & $\begin{array}{c}620.19 \\
6\end{array}$ & 59 & 10.512 & & & \\
\hline
\end{tabular}

\begin{tabular}{|c|c|c|c|c|c|c|}
\hline Total & $\begin{array}{c}314332 \\
.000\end{array}$ & 62 & & & & \\
\hline Corrected Total & $\begin{array}{c}652.96 \\
8\end{array}$ & 61 & & & & \\
\hline \multicolumn{7}{|l|}{6} \\
\hline
\end{tabular}

$\mathrm{P}>0.05$

Table 2 shows that at 0.05 level of significance, $1 \mathrm{df}$ numerator and $61 \mathrm{df}$ denominator, the calculated $\mathrm{F}$ is 1.811 with Pvalue of 0.184 which is more than the stipulated 0.05 level of significance. Thus, the null hypothesis is accepted. The effect of Modelling technique in enhancing secondary school students' Academic self-concept is not significant.

\section{Null Hypothesis 2}

There is no significant difference in the effects of Modelling and Assertiveness techniques on secondary school students' Academic self-concept using their Academic self-concept mean scores.

Table 3: ANCOVA on the post-test Academic self-concept mean scores of students treated with Modelling technique and those treated with Assertiveness technique.

\begin{tabular}{|c|c|c|c|c|c|c|}
\hline \multicolumn{10}{|c|}{$\begin{array}{c}\text { Source of } \\
\text { Variation }\end{array}$} & $\begin{array}{c}\text { Sum of } \\
\text { Squares }\end{array}$ & df & $\begin{array}{c}\text { Mean } \\
\text { Square }\end{array}$ & $\begin{array}{c}\text { Cal. } \\
\mathrm{F}\end{array}$ & $\begin{array}{c}\text { Pvalu } \\
\mathrm{e}\end{array}$ & $\begin{array}{c}\text { Decisio } \\
\mathrm{n}\end{array}$ \\
\hline $\begin{array}{c}\text { Corrected } \\
\text { Model }\end{array}$ & 7631.314 & 2 & $\begin{array}{c}3815.6 \\
57\end{array}$ & $\begin{array}{c}90.17 \\
2\end{array}$ & .000 & \\
\hline Intercept & 1838.987 & 1 & $\begin{array}{c}1838.9 \\
87\end{array}$ & $\begin{array}{c}43.45 \\
9\end{array}$ & .000 & \\
\hline PRETEST & .765 & 1 & .765 & .018 & .893 & \\
\hline GROUP & 5948.048 & 1 & $\begin{array}{c}5948.0 \\
48\end{array}$ & $\begin{array}{c}140.5 \\
66\end{array}$ & .000 & $\mathrm{~S}$ \\
\hline Error & 2665.853 & 63 & 42.315 & & & \\
\hline Total & 463147.000 & 66 & & & & \\
\hline $\begin{array}{c}\text { Corrected } \\
\text { Total }\end{array}$ & 10297.167 & 65 & & & & \\
\hline \multicolumn{7}{|c|}{} \\
\hline
\end{tabular}

$\mathrm{P}<0.05$

Table 3 reveals that at 0.05 level of significance, $1 \mathrm{df}$ numerator and 65dfdenominator, the calculated $\mathrm{F}$ is 42.315 with Pvalue of 0.001 which is less than the stipulated 0.05 level of significance. Therefore, the null hypothesis is rejected. So, there is a significant difference in the effects of Modelling and Assertiveness techniques on secondary school students' Academic self-concepts.

\section{DISCUSSION}

Findings of this study were discussed as follows:

The effect of modelling technique in enhancing Academic selfconcepts of secondary school students

The findings of this study revealed that Modelling technique is not effective in enhancing Academic self-concepts of secondary school students. The findings further revealed that the effect of Modelling technique on secondary school students' Academic self-concepts when compared with those 
who received conventional counselling is not significant. What this means is that the improvement recorded by the students who were exposed to therapy using Modelling technique is not far different from those who were exposed to the conventional group counselling and that Modelling technique did not have substantial impact in enhancing academic self-concept of secondary school students.

This finding of the study is surprising and contrary to expectation of the researcher. It was expected that the process of learning by watching others which is a therapeutic technique used to effect behavioural change, would create substantially impact on the academic self-concept of the students. This however is not the case with the findings of the present study. The finding of the study however is in agreement with the findings of Bisri, Purwanto and Japar (2018). The results of the study by Bisri, Purwanto and Japar indicate that students who received group counselling services with combined techniques experienced improved self-efficacy of advanced study decision making higher than students who received group counselling services with live modelling technique.

The reason for this finding could be linked to the view expressed by Solomon and O'Brien (2016) that Modelling when used alone has been shown to be effective in modifying some undesirable behaviour, depending on the duration of training and the characteristics of the model. Going by Solomon and O'Brien assertion, it is possible to attribute the finding to the characteristics of the model or the duration of the therapy as used in this study may be considered as not being enough to make a lasting change in the participants' behaviour.

The above view is supported by Albert Bandura, who studied observational learning in children. Bandura noted that there are certain conditions that determine whether or not people learn from observed behaviour. The conditions listed by Bandura include that those who receive the therapy must pay attention and retain what they have observed, and they must be capable of and motivated to reproduce the behaviour. Bandura further noted that the effects of observed behaviour are also stronger if the model has characteristics similar to those of the observer or is particularly attractive or powerful. It is possible that one of these conditions may not have been met in the current study.

Although the finding of this current study showed that there was an enhancement in the academic self-concept of the student participants, as indicated with the treatment group's mean gain over the control group, the finding is considered not effective on the basis that the post-test mean treatment score of the experimental group is below the Academic Selfconcept Inventory norm, indicating that those that were exposed to the Modelling technique were still within the problem group. To further explain this finding, Nnodum (2010) whose study revealed that the treatment using Modelling technique was effective and superior to the Control condition in improving the social skills of isolates and reducing their isolate behaviour. The reason for Nnodum's finding could be explained using Brewer (1998) discovery that Modelling has been shown to be effective when embedded into such group programs as social skills training and assertiveness training as well as in individual therapy. The finding thus is an indication that though Modelling technique standing alone may be effective in handling some behavioural problems, however, it was not effective in enhancing academic self-concept of secondary school students in Onitsha Education zone.

The effect ofmodelling technique in enhancing Academic selfconcepts of male and female secondary school students

The findings of the study revealed that the difference in the effects of Modelling technique on male and female secondary school students' Academic self-concepts is not significant. This means that both the male and female students responded to the treatment using Modelling technique in the same way and that the treatment has similar effects on both male and female secondary school students. Although male and female are known to differ in personality characteristics, both biologically and in gender role socialisation, the finding of this study is not surprising going by the understanding that both male and female participants were exposed to the same therapeutic condition using the same Models.

Moreover, previous research comparing gender distinctiveness aspects between boys and girls has shown mixed results. On the one hand, boys were shown to have higher levels of own-versus other-gender similarity (Martin, Andrews, England, Zosuls\&Ruble, 2017) and felt pressure to behave in line with gender norms than girls have (Egan \& Perry, 2001). Some research has shown that girls score higher on gender centrality and identify more strongly with the gender in-group than men (Cadinu\&Galdi, 2012), while no gender differences were found for gender typicality (Dambrun, Duarte, \&Guimond, 2004).

Therefore, the ability of males and females as members of separate categories is a fundamental aspect of learning. So, observational learning from available models, especially same-gender models, in the child's environment is an important factor in learning through modelling. Thus, the finding of this study could be attributed to the fact that the researcher took cognisance of this notion and ensured that both male and female models were used in the study.The students (both male and female) thus must have paid attention to the models and encoded their behaviour in a similar way. Hence, the result of the study that there is no significant difference in the mean post-test academic self-concept scores of students exposed to Modelling technique may not have happened by chance.

\section{CONCLUSIONS}

Based on the findings of this study, the following conclusions are made: 
This study provided evidence that academic self-concept of secondary school students could be enhanced when they are treated with Modelling technique. However, based on the finding of this study, it is concluded that modelling technique do not have significant effect on the academic self-concept of both male and female secondary school students.

\section{RECOMMENDATIONS}

Based on the findings of this study, the following recommendations are made:

1. The classroom teacher should be put on alert to identify students with low academic self-concept so that appropriate referral to the school guidance counsellor would make.

2. Modelling technique could enhance the academic selfconcept of secondary school students, however, the use of the technique in counselling and therapy should be complemented with other effective techniques for more effective treatment of students with low academic selfconcept.

\section{REFERENCES}

[1] Cadinu, M., \&Galdi, S. (2012). Gender differences in implicit gender self-categorization lead to stronger gender self-stereotyping by women than by men. European Journal of Social Psychology, 42, 546-551.doi:10.1002/ejsp.1881

[2] Clark, H.W.S. (2016). Effect of whole brain teaching on student self-concept (Published Dissertation) Walden Dissertations and Doctoral Studies, Walden University.

[3] Dambrun, M., Duarte, S., \&Guimond, S. (2004). Why are men more likely to support group-based dominance than women? The mediating role of gender identification.British Journal of Social Psychology, 43, 287-297.doi:10.1348/0144666041501714

[4] Dramanu, B.Y. \&Balarabe, M. (2013).Effects of math selfconcept, perceived self-efficacy, and attributions for failure and success on test anxiety. European Scientific Journal, 9(34), 18577881.
[5] Egan, S. K., Perry, D. G. (2001). Gender identity: A multidimensional analysis with implications for psychosocial adjustment. Developmental Psychology, 37, 451-463.

[6] Frank, M. A. (2011). The pillars of the self-concept: Self-esteem and self-efficacy. Retrieved from http://www.excelatlife.com/articles/selfesteem

[7] Hardy, G. (2013). Academic self-concept: Modeling and measuring for science. Springers.doi: 10.1007/s11165-013-9393-7

[8] Hattie, J. A. C. (2012). Visible learning for teachers. London, UK: Routledge.

[9] La Shawn C. (2011). The University of Lowa, Counselor Education and supervision. Cell: 678-438-9808. Retrieved from www.uiowa.edu.

[10] Liem, G. A., McInerney, D. M., Yeung, A. S. (2015). Academic self-concepts in ability streams: Considering domain specificity and same-stream peers. The Journal of Experimental Education, 83, 83-109. Retrieved from http://eric.ed.gov/

[11] Liu, W. C, and Wang, C.K. J. (2008). Home environment and classroom climate: investigation of their relation to students' academic self-concept in a streamed setting. Current Psychology,27,242-256.Doi:10.1007/512144-008-9037-7.

[12] Martin, C. L., Andrews, N. C. Z., England, D. E., Zosuls, K., Ruble, D. N. (2017). A dual identity approach for conceptualizing and measuring children's gender identity.Child Development, $88,167-182$.

[13] Marsh, H. W. and Craven, R.G. (1997). Academic self-concept: Beyond the dustbowl. In G. Phye (Ed.) Handbook of classroom assessment: Learning, achievement and adjustment. US: Academic Press.

[14] McLeod, S. A. (2016, Feb 05). Bandura - social learning theory. Retrieved from https://www.simplypsychology.org/bandura.html

[15] Nnodum, B.I. (2010). Relative effectiveness of assertive training, modelling and their combination in the reduction of isolate behaviour in children. Edo Journal of Counselling, 3(1), 1-15. Retrieved from https://www.ajol.info/index.

[16] Olatunde, T.P. (2010). Students' self-concept and Mathematics achievement in some secondary schools in South Western Nigeria.European journal of social sciences, 13 (1), 127-132.

[17] Olorunfemi-Olabisi, F.A. \&Akomolafe, M.J. (2013).Effects of self-management technique on academic self-concept of underachievers in secondary schools.Journal of Education and Practice, 4(6), 138-142. Retrieved from http://www.iiste.org.

[18] Westen, D.; Burton, L. \& Kowalski, R. (2006) Psychology: Australian and New Zealand Edition. Milton, QLD. John Wiley and Sons. 